\title{
Conversion of Formic Acid into Methanol Using a Bipyridine-functionalized Molecular Heterogeneous Catalyst
}

\author{
Sudipta De ${ }^{\dagger}$ Lieven Gevers, ${ }^{\dagger}$ Abdul-Hamid Emwas, ${ }^{\ddagger}$ and Jorge Gascon ${ }^{\dagger *}$ \\ $\dagger$ King Abdullah University of Science and Technology, KAUST Catalysis Center (KCC), Advanced \\ Catalytic Materials, Thuwal 23955, Saudi Arabia \\ * King Abdullah University of Science and Technology, Core Labs, Thuwal 23955, Saudi Arabia \\ *Corresponding author e-mail: jorge.gascon@kaust.edu.sa
}

\begin{abstract}
Although the conversion of carbon dioxide (and its derivatives) into methanol has attracted remarkable attention in the last two decades, performing this process over a heterogeneous catalyst under mild conditions is still a challenging task. We report bipyridine-functionalized iridium-based heterogeneous catalysts for the hydrogenation of formic acid to produce methanol at low temperature. The solid catalysts were obtained by post-synthetic metalation of bipyridine-functionalized organosilica nanotubes with a $\left[\mathrm{Cp} * \operatorname{Ir}\left(\mathrm{H}_{2} \mathrm{O}\right)_{3}\right] \mathrm{SO}_{4}\left(\mathrm{Cp}^{*}=\eta^{5}\right.$-pentamethylcyclopentadienyl) complex. Detailed studies including $\mathrm{N}_{2}$ adsorption, TEM, XPS, and ${ }^{13} \mathrm{C}$ CP MAS NMR confirmed the stable structures of nanotube supports and the molecular nature of the active species. The catalysts showed competitive methanol selectivities compared to their homogeneous counterpart under similar reaction conditions. Addition of strong acids (such as triflic acid) showed improved methanol selectivity, whereas the presence of free bipyridine groups was found to promote the dehydrogenation of formic acid, resulting in low methanol selectivity. The catalyst showed excellent reusability over four consecutive cycles without any significant loss in activity and maintained its heterogeneous nature in extremely high acidic environment.
\end{abstract}

KEYWORDS: Hydrogen storage, Methanol production, Hydrogenation of formic acid, Molecular heterogeneous catalysis, Iridium-bipyridine complex 


\section{INTRODUCTION}

Methanol is currently considered as a potential liquid chemical hydrogen storage (CHS) material with a storage capacity of $12.6 \mathrm{wt} \% \mathrm{H}_{2} .{ }^{1}$ It is used as a raw material for the chemical industry, ${ }^{2}$ and is an intermediate for the production of various basic chemical building blocks, including methyl tert-butyl ether, formaldehyde and acetic acid. ${ }^{3}$ Moreover, its high octane number has made it a suitable alternative fuel for internal combustion engines. ${ }^{4}$

Current industrial production of methanol is mainly based on the conversion syngas at moderate temperatures $\left(250-300{ }^{\circ} \mathrm{C}\right)$ and high pressures (50-100 bar) using a copper-zinc-based oxide catalyst. ${ }^{5-6}$ The use of syngas in methanol production involves multi-stage and complex technology with all its limitations and costs. Given that carbon dioxide $\left(\mathrm{CO}_{2}\right)$ is an inexpensive source of carbon and highly abundant in the atmosphere, it is expected that using $\mathrm{CO}_{2}$ as a feedstock will benefit the society economically and environmentally. Current practical applications for the conversion of $\mathrm{CO}_{2}$ and $\mathrm{H}_{2}$ into methanol are entirely based on heterogeneous catalysis. The George Olah $\mathrm{CO}_{2}$ to Renewable Methanol Plant in Iceland produces 3500 tons of methanol per year and Silicon Fire AG produces 50 tons of methanol per day. ${ }^{7}$

In order to perform the above mentioned process under relatively milder conditions, many groups studied homogeneous catalysts, mainly based on transition metals, ${ }^{1,-11}$ frustrated Lewis pairs, ${ }^{12-14}$ and Nheterocyclic carbenes. ${ }^{15-16}$ However, the high activation barrier of $\mathrm{CO}_{2}$ still makes the direct hydrogenation of $\mathrm{CO}_{2}$ to methanol challenging. Since $\mathrm{CO}_{2}$ derivatives have lower activation barrier than $\mathrm{CO}_{2}$, an alternative option could be replacing $\mathrm{CO}_{2}$ by its derivatives as substrates. In 2011, the Milstein group reported the hydrogenation of $\mathrm{CO}_{2}$ derivatives, such as carbonates, carbamates, formates, and urea to afford methanol with high yield and high turnover number (TON). ${ }^{17-18}$ Later, Ding and co-workers reported a highly active Ru-MACHO catalyst for the hydrogenation of cyclic carbonates derived from $\mathrm{CO}_{2}$ and epoxide with an impressive TON of $87000 .{ }^{19}$ Recently, the disproportionation of formic acid $\left(\mathrm{HCO}_{2} \mathrm{H}\right)$ has been shown to offer an alternative path to overcome challenges related to the direct hydrogenation of $\mathrm{CO}_{2}{ }^{20-27}$ Based on the development of several matured technologies for the production of formic acid from direct hydrogenation of $\mathrm{CO}_{2}, 1,3,8,28$ it is expected that the use of formic acid as substrate would be another way out. Typically, homogeneous catalysts were explored for the conversion of formic acid, among which iridium-based complexes produced the most promising results. ${ }^{20,22-24,29}$

Here we report the first example of a heterogeneous catalyst, based on $\left[\mathrm{Cp} * \operatorname{Ir}\left(\mathrm{H}_{2} \mathrm{O}\right)_{3}\right] \mathrm{SO}_{4}$, for the hydrogenation of formic acid to methanol. We used a robust support for the immobilization of the $\left[\mathrm{Cp} * \operatorname{Ir}\left(\mathrm{H}_{2} \mathrm{O}\right)_{3}\right] \mathrm{SO}_{4}$ complex to achieve a heterogeneous catalyst, where the active catalytic centers keep 
their identity upon heterogenization. We have applied different characterization techniques to confirm the successful grafting of molecular species and studied their performance in the hydrogenation of formic acid.

\section{EXPERIMENTAL SECTION}

\section{Catalyst Characterization and Analysis}

$\mathrm{N}_{2}$ physisorption studies were performed at $77 \mathrm{~K}$ on a Micromeritics Asasp 2040 instrument. All samples were evacuated at $333 \mathrm{~K}$ for $16 \mathrm{~h}$. The specific surface area and pore size distributions were obtained by the Brunauer-Emmett-Teller and the Barrett-Joyner-Halenda methods using the adsorption branch.

Transmission electron microscopes (TEM) were operated on a Tecnai-Twin system at $120 \mathrm{kV}$. Samples were dispersed in chloroform before placing them on the TEM grid.

Carbon, hydrogen, nitrogen and sulfur contents were determined by CHNS elemental analysis on a Thermo Scientific FlashEA 1112 elemental analyzer.

Iridium content was measured by using ICP-OES on an Agilent 5100 system. $30 \mathrm{mg}$ of catalyst was digested using a mixture of $6 \mathrm{~mL}$ aqua regia and $1 \mathrm{~mL}$ hydrofluoric acid at $373 \mathrm{~K}$ for $2 \mathrm{~h}$.

X-ray fluorescence (XRF) measurements were performed on a HORIBA XGT-700 instrument. For each sample, 3 different spots were analyzed with a total analysis time of $1800 \mathrm{~s}$.

Liquid NMR spectra were recorded on a Bruker Avance 400 spectrometer in deuterated solvents. ${ }^{1} \mathrm{H}$ NMR chemical shifts were referenced to the residual hydrogen signals of the deuterated solvents (7.28 ppm, $\mathrm{CDCl}_{3} ; 4.70 \mathrm{ppm}, \mathrm{D}_{2} \mathrm{O}$ ), and the ${ }^{13} \mathrm{C} \mathrm{NMR}$ chemical shifts were referenced to the ${ }^{13} \mathrm{C}$ signal of the deuterated solvent $\left(77.0 \mathrm{ppm}, \mathrm{CDCl}_{3}\right)$.

For the solid state NMR study, all NMR spectra were acquired using a Bruker $400 \mathrm{MHz}$ AVANACIII NMR spectrometer equipped with a $4 \mathrm{~mm}$ Bruker double resonance MAS probe (BrukerBioSpin, Rheinstetten, Germany). The samples were packed evenly into a $4 \mathrm{~mm}$ zirconia rotor and sealed at the open end with a Vespel cap. The ${ }^{13} \mathrm{C}$ NMR spectra were recorded with $14 \mathrm{kHz}$ and 12 $\mathrm{kHz}$ spinning rate using cross polarization $(\mathrm{CP})$ pulse program. To achieve high signal to noise ratio, the spectra were recorded by collecting at least $12 \mathrm{k}$ scans with recycle delay time of $5 \mathrm{~s}$. Bruker Topspin 3.5pl7 software (Bruker BioSpin, Rheinstetten, Germany) was used for data collection and MestReNova software was used for data analysis. 
X-ray photoelectron spectra (XPS) were recorded on an Axis Ultra DLD (Kratos Tech.) equipment using a monochromatic $\mathrm{Al} \mathrm{K \alpha}$ source $(\mathrm{h} v=1486.6 \mathrm{eV}, 15 \mathrm{kV}, 10 \mathrm{~mA})$. For the calibration measurement, $\mathrm{C} 1 \mathrm{~s}$ peak at $284.5 \mathrm{eV}$ was used as reference standard to calibrate the binding energy. XPS data were processed on a CasaXPS software.

Quantitative analysis of the reaction products was conducted on a GC (Agilent 7890A) equipped with an FID detector and DB-WAX column $(20 \mathrm{~m} \times 0.18 \mathrm{~mm} \times 0.18 \mu \mathrm{m})$. Essential parameters of the GC analysis were as follows: injection volume $1 \mu \mathrm{L}$, inlet temperature $260{ }^{\circ} \mathrm{C}$, detector temperature $250{ }^{\circ} \mathrm{C}$, and a split ratio of $1: 100$. The initial column temperature was $40{ }^{\circ} \mathrm{C}$ (hold time $1 \mathrm{~min}$ ) and it was increased to $70{ }^{\circ} \mathrm{C}$ with a temperature ramp of $8{ }^{\circ} \mathrm{C} \mathrm{min}^{-1}$ and then to the final temperature of $240{ }^{\circ} \mathrm{C}$ (hold time $1 \mathrm{~min}$ ) with a temperature ramp of $20^{\circ} \mathrm{C} \mathrm{min}^{-1}$.

\section{Synthesis of Catalysts}

\section{Chemicals}

4,4'-dimethyl-2,2'-bipyridine (99\%), $n$-butyllithium ( $n$-BuLi; $1.6 \mathrm{M}$ in hexane), tetrahydrofuran (THF; anhydrous), triblock copolymer $\mathrm{EO}_{20} \mathrm{PO}_{70} \mathrm{EO}_{20}$ (Pluronic P123, M.W. = 5800), (3-chloropropyl)trimethoxylsilane $\quad(\geq \quad 97 \%), \quad$ 1,4-bis(triethoxysilyl)benzene $\quad$ (BTEB, 96\%), pentamethylcyclopentadienyliridium(III) chloride dimer $\left(\left[\mathrm{Cp}^{*} \mathrm{IrCl}_{2}\right]_{2}\right)(96 \%)$, silver sulfate (> 99.5\%), 2,2'-bipyridine, formic acid ( $\geq 98 \%$ ) were purchased from Sigma-Aldrich and used without further purification.

Synthesis of $\left[\mathrm{Cp}^{*} \operatorname{Ir}\left(\mathrm{H}_{2} \mathrm{O}\right)_{3}\right] \mathrm{SO}_{4}$

A mixture of $[\mathrm{Cp} * \operatorname{IrCl}(\mu-\mathrm{Cl})]_{2}(0.24 \mathrm{~g}, 0.3 \mathrm{mmol})$ and $\mathrm{Ag}_{2} \mathrm{SO}_{4}(0.187 \mathrm{~g}, 0.6 \mathrm{mmol})$ in $\mathrm{H}_{2} \mathrm{O}(2 \mathrm{~mL})$ was stirred at room temperature for $12 \mathrm{~h}$ under an argon atmosphere. $\mathrm{AgCl}$ was started to precipitate which was removed by filtration. The solvent was then evaporated and the residue was dried in vacuum to yield a yellow product of $\left[\mathrm{Cp} * \operatorname{Ir}\left(\mathrm{H}_{2} \mathrm{O}\right)_{3}\right] \mathrm{SO}_{4}$ (yield: $98 \%$ based on $[\mathrm{Cp} * \operatorname{IrCl}(\mu-\mathrm{Cl})]_{2} .{ }^{1} \mathrm{H} \mathrm{NMR}\left(\mathrm{D}_{2} \mathrm{O}, 400 \mathrm{MHz}\right)$ : $\delta=1.58\left(\mathrm{~s} ; \mathrm{Cp}^{*}\right)$.

\section{Synthesis of 4,4'-[4-(Trimethoxysilanyl)butyl]-2,2'-bipyridine (1)}

To a $100 \mathrm{~mL}$ flask, $0.224 \mathrm{~g}$ diisopropylamine and $6 \mathrm{~mL}$ anhydrous THF were added under argon atmosphere. After the temperature of the solution was set at $0{ }^{\circ} \mathrm{C}, 2.58 \mathrm{~mL} n$-BuLi (1.6 M, $\left.4 \mathrm{mmol}\right)$ was added dropwise and the mixture was stirred for $30 \mathrm{~min}$. A solution of $0.369 \mathrm{~g} \mathrm{4,4'-dimethyl-2,2'-}$ bipyridine ( $2 \mathrm{mmol}$ ) in $15 \mathrm{~mL}$ anhydrous THF was slowly added to this mixture and stirred for an additional $1 \mathrm{~h} \quad$ at $\quad 0 \quad{ }^{\circ} \mathrm{C}$ under argon. To this mixture, a solution of $0.796 \mathrm{~g}$ (3- 
chloropropyl)trimethoxylsilane $(0.73 \mathrm{~mL}, 4 \mathrm{mmol})$ in $2 \mathrm{~mL}$ anhydrous THF was then added slowly and stirred for $2 \mathrm{~h}$. Temperature of the reaction mixture was then allowed to increase to room temperature and then stirred for overnight. The reaction was quenched with $0.2 \mathrm{~mL}$ of acetone, and the remaining solvent and (3-chloropropyl)trimethoxylsilane (if any) were removed by vacuum distillation. Alkoxysilanemodified 2,2'-bipyridine was obtained as a pale yellow solid, which was then dried under vacuum at room temperature for several hours and finally stored under argon atmosphere. ${ }^{1} \mathrm{H}$ NMR $\left(\mathrm{CDCl}_{3}, 400 \mathrm{MHz}\right): \delta$ $=8.55(\mathrm{~m}, 2 \mathrm{H}, \mathrm{Py}), 8.23$ (s, 2H, Py), 7.15 (d, J=5 Hz, 2H, Py), 3.47 (s, 18H, OMe), 2.72 (t, J = 7.6 Hz,

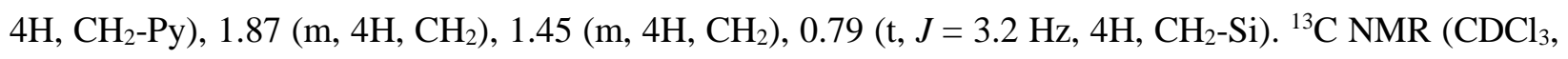
$400 \mathrm{MHz}): \delta=9.0,14.0,33.7,35.2,50.5,122.0,124.7,148.3,149.0,155.9$. Elemental analysis of $\mathrm{C}_{24} \mathrm{H}_{40} \mathrm{~N}_{2} \mathrm{O}_{6} \mathrm{Si}_{2}: \mathrm{C}=56.67 \%, \mathrm{H}=7.93 \%, \mathrm{~N}=5.51 \%$; found: $\mathrm{C}=52.92 \%, \mathrm{H}=7.41 \%, \mathrm{~N}=5.64 \%$.

Synthesis of BPy-NT

The synthesis of organosilica nanotubes was adopted from previous reports with slight modifications. ${ }^{30-31}$ In a typical synthesis, $0.4 \mathrm{~g}$ of $\mathrm{P} 123$ copolymer and $1.3 \mathrm{~g}$ of $\mathrm{KCl}$ were dissolved in $100 \mathrm{ml} 2.0 \mathrm{M} \mathrm{HCl}$ solution at $38{ }^{\circ} \mathrm{C}$. After the dissolution of P123, $0.714 \mathrm{~mL}$ of 1, 4-bis(triethoxysilyl)benzene (BTEB, 1.8 mmol) (2) was slowly added to this solution with vigorous stirring. The mixture was kept stirring for $12 \mathrm{~h}$ at $38^{\circ} \mathrm{C}$, and then $0.2 \mathrm{mmol}$ of (1) dissolved in $2 \mathrm{ml}$ THF was added dropwise to keep the molar ratio of compound (1) to BTEB (2) as 1:9. The resulting mixture was stirred at $38^{\circ} \mathrm{C}$ for $24 \mathrm{~h}$ and then transferred to a PTFE hydrothermal reactor. The reactor was placed inside the oven at $100{ }^{\circ} \mathrm{C}$ for $24 \mathrm{~h}$. The solid product was filtered and dried at room temperature overnight. Finally, the P123 template was removed by refluxing $1.0 \mathrm{~g}$ of the solid product in $200 \mathrm{ml}$ of ethanol containing $1.27 \mathrm{~g}$ concentrated $\mathrm{HCl}$ for $24 \mathrm{~h}$. The obtained sample was denoted as BPy-NT-1/9. Other two samples with molar ratio of compound (1) to BTEB (2) 1:6 and 1:3 were also synthesized using the same method.

\section{Synthesis of $C p * I r-B P y-N T$}

To prepare the iridium-immobilized nanotube catalysts, $200 \mathrm{mg}$ BPy-NT was added to a solution of $\left[\mathrm{Cp} * \operatorname{Ir}\left(\mathrm{H}_{2} \mathrm{O}\right)_{3}\right] \mathrm{SO}_{4}$ (equivalent amount of total bipyridine) in $30 \mathrm{ml}$ anhydrous ethanol under argon atmosphere and stirred under refluxing conditions for $24 \mathrm{~h}$. The solid product was isolated by filtration and thoroughly washed with anhydrous ethanol to remove unreacted $\left[\mathrm{Cp} * \operatorname{Ir}\left(\mathrm{H}_{2} \mathrm{O}\right)_{3}\right] \mathrm{SO}_{4}$. The samples were dried under vacuum at $50{ }^{\circ} \mathrm{C}$ and named as Ir-BPy-NT-x/y, where $\mathrm{x} / \mathrm{y}=1 / 9,1 / 6$ and $1 / 3$, respectively, corresponding to the molar ratio of bipyridine- to benzene-bridged precursor compound (1) in the initial synthesis of BPy-NT.

Synthesis of $\left[\mathrm{Cp} * \operatorname{Ir}(\right.$ bpy $\left.)\left(\mathrm{H}_{2} \mathrm{O}\right)\right] \mathrm{SO}_{4}$ 
A mixture of 2,2'-bipyridine (31.2 mg, $0.2 \mathrm{mmol}),\left[\mathrm{Cp} * \operatorname{Ir}\left(\mathrm{H}_{2} \mathrm{O}\right)_{3}\right] \mathrm{SO}_{4}(107.2 \mathrm{mg}, 0.2 \mathrm{mmol})$, and water (4

$\mathrm{mL}$ ) was stirred under argon atmosphere for $18 \mathrm{~h}$ at room temperature. The solution was evaporated to obtain a yellow solid product quantitatively. ${ }^{1} \mathrm{H}$ NMR $\left(400 \mathrm{MHz}, \mathrm{D}_{2} \mathrm{O}\right) \delta=9.05(\mathrm{~d}, J=4.9 \mathrm{~Hz}, 2 \mathrm{H}, \mathrm{Ar}$ H), $8.48(\mathrm{~d}, J=7.9 \mathrm{~Hz}, 2 \mathrm{H}, \mathrm{Ar} \mathrm{H}), 8.27$ (td, $J=7.8,1.2 \mathrm{~Hz}, 2 \mathrm{H}, \mathrm{Ar} \mathrm{H}), 7.82$ (ddd, $J=7.2,3.8,1.2 \mathrm{~Hz}$, $2 \mathrm{H}, \mathrm{Ar} \mathrm{H}), 1.60$ (s, 15H, Cp*).

Synthesis of $\left[\mathrm{Cp} * \operatorname{Ir}(\right.$ dmbpy $\left.)\left(\mathrm{H}_{2} \mathrm{O}\right)\right] \mathrm{SO}_{4}$

A mixture of 4,4'-dimethyl-2,2'-bipyridine (36.8 mg, $0.2 \mathrm{mmol}),\left[\mathrm{Cp} * \operatorname{Ir}\left(\mathrm{H}_{2} \mathrm{O}\right)_{3}\right] \mathrm{SO}_{4}$ (107.2 $\mathrm{mg}, 0.2$ $\mathrm{mmol})$, and water $(4 \mathrm{~mL})$ was stirred under argon atmosphere for $18 \mathrm{~h}$ at room temperature. The solution was evaporated to obtain a yellow solid product quantitatively. ${ }^{1} \mathrm{H}$ NMR $\left(400 \mathrm{MHz}, \mathrm{D}_{2} \mathrm{O}\right) \delta=8.80(\mathrm{~d}, J=$ $5.8 \mathrm{~Hz}, 2 \mathrm{H}, \mathrm{Ar} \mathrm{H}), 8.23$ (s, 2H, Ar H), 7.59 (dd, J = 5.8, $1.0 \mathrm{~Hz}, 2 \mathrm{H}, \mathrm{Ar} \mathrm{H}), 2.52$ (s, 6H, CH $3-\mathrm{Py}), 1.55$ (s, $15 \mathrm{H}, \mathrm{Cp} *)$.

\section{Procedure of $\mathrm{HCO}_{2} \mathrm{H}$ Hydrogenation Reaction}

The hydrogenation of $\mathrm{HCO}_{2} \mathrm{H}$ was carried out in an AMTECH SPR16 batch reactor equipped with temperature and pressure controller for each reactor vessel. The reactor was charged with substrate (generally formic acid solution in water) and catalyst. The reactor was then flushed with argon (10 bar) for at least 2 times and checked leakages (if any) by charging the reactor with argon (50 bar) one more time. The reactor was filled with hydrogen at certain pressure and then set to a desired temperature for certain time. After the reaction, the reactor was cooled down to room temperature or lower and the pressure was slowly released until atmospheric pressure and the liquid samples were collected for analysis. $\mathrm{HCO}_{2} \mathrm{H}$ conversion $\left(X_{\mathrm{HCO}} \mathrm{H}\right), \mathrm{MeOH}$ yield $\left(Y_{\mathrm{MeOH}}\right), \mathrm{MeOH}$ selectivity $\left(S_{\mathrm{MeOH}}\right)$ and $\mathrm{TOF}$ of $\mathrm{MeOH}\left(\mathrm{TOF}_{\mathrm{MeOH}}\right)$ were calculated according to the following equations. Methyl formate $\left(\mathrm{HCO}_{2} \mathrm{Me}\right)$ was also taken into account as it was also found to form under acidic conditions.

$$
\begin{aligned}
& X_{\mathrm{HCO}_{2} \mathrm{H}}=\frac{n_{\mathrm{HCO}_{2} \mathrm{H}(\text { initial })}-\left(n_{\mathrm{HCO}_{2} \mathrm{H}(\text { final })}+n_{\mathrm{HCO}_{2} \mathrm{Me}}\right)}{n_{\mathrm{HCO}_{2} \mathrm{H}(\text { initial })}} \times 100 \% \\
& Y_{\mathrm{MeOH}}=\frac{n_{\left(\mathrm{MeOH}+\mathrm{HCO}_{2} \mathrm{Me}\right)}}{n_{\mathrm{HCO}_{2} \mathrm{H} \text { (initial) }}} \times 100 \% \\
& S_{\mathrm{MeOH}}=\frac{n_{\left(\mathrm{MeOH}+\mathrm{HCO}_{2} \mathrm{Me}\right)}}{n_{\mathrm{HCO}_{2} \mathrm{H} \text { (initial) }}-\left(n_{\mathrm{HCO}_{2} \mathrm{H}(\text { final })}+n_{\mathrm{HCO}_{2} \mathrm{Me}}\right)} \times 100 \% \\
& \mathrm{TOF}_{\mathrm{MeOH}}=\frac{n_{\left(\mathrm{MeOH}+\mathrm{HCO}_{2} \mathrm{Me}\right)}}{n_{\mathrm{Ir}} \times t}
\end{aligned}
$$




\section{RESULTS AND DISCUSSION}

The bipyridine-silica nanotubes (BPy-NTs) were synthesized using 1,4-bis(triethoxysilyl)benzene (BTEB) as precursor and P123 copolymer as soft surfactant with $\mathrm{KCl}$ as additive. From the TEM images, it is clearly observed that the materials have hollow interior, indicating the formation of the nanotubes (Figure 1 and S2). The nanotubes have inner diameter of 6-7 nm and wall thickness of 3-3.5 nm. Using the bipyridine-functionalized nanotubes as a support, we synthesized a molecular heterogeneous catalyst, $\mathrm{Cp} *$ Ir-BPy-NT $\left(\mathrm{Cp}^{*}=\eta^{5}\right.$-pentamethylcyclopentadienyl $)$, through iridium post-synthetic metalation of BPy-NT.
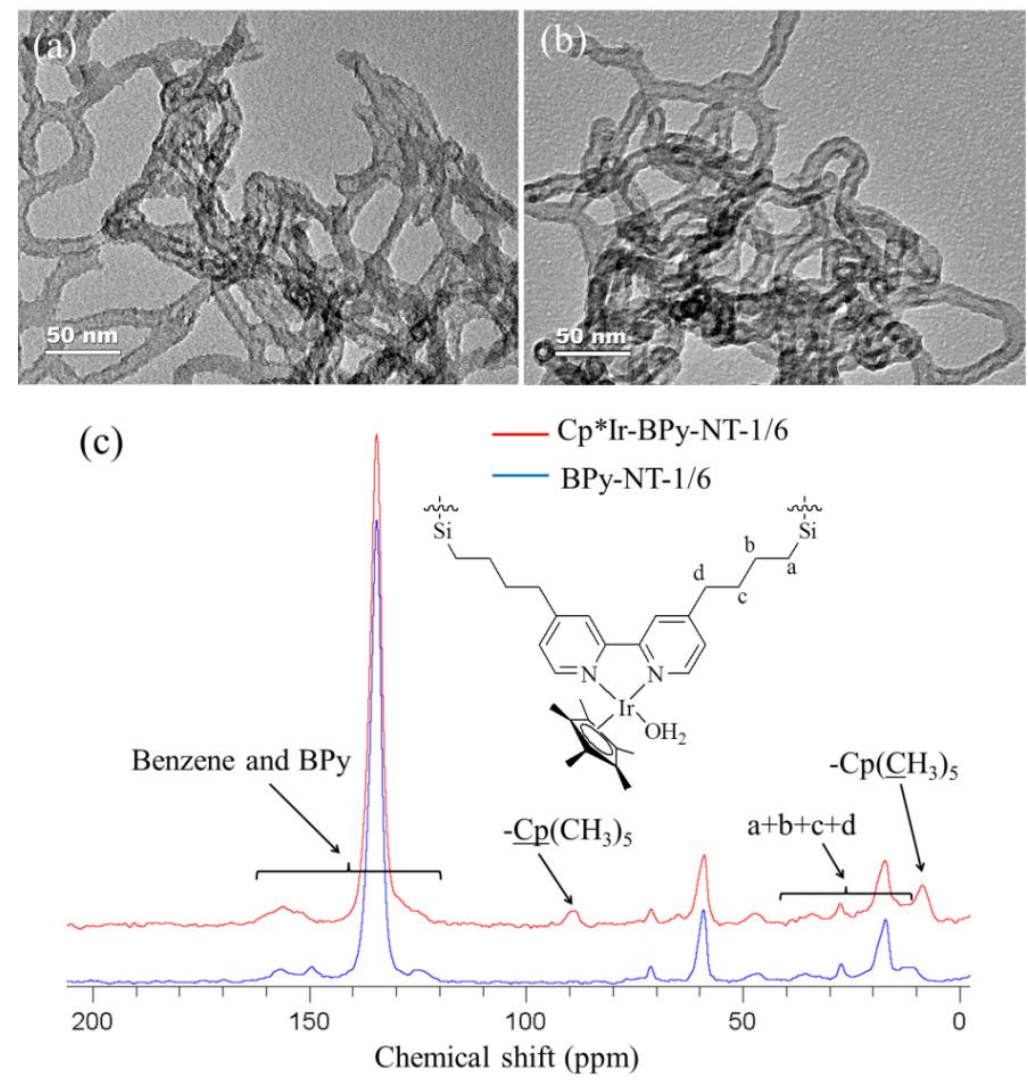

Figure 1. TEM images of (a) BPy-NT-1/6 and (b) Ir-BPy-NT-1/6. (c) ${ }^{13} \mathrm{C}$ CP MAS NMR spectra of BPyNT-1/6 (blue line) and Cp*Ir-BPy-NT-1/6 (red line).

The nanotube structure was maintained after loading the iridium complex, as shown in Figure $1 \mathrm{~b}$. The incorporation of $\mathrm{Cp} * \mathrm{Ir}$ group on BPy-NT-1/6 was confirmed by solid-state ${ }^{13} \mathrm{C}$ cross polarization magic-angle spinning (CP MAS) NMR spectroscopy (Figure 1c). New signals observed at 9 and 90 ppm in the ${ }^{13} \mathrm{C}$ CP MAS NMR spectrum of Cp*Ir-BPy-NT-1/6, compared to that of BPy-NT-1/6, can be attributed to the $\mathrm{Cp}^{*}$ ligand. XPS analysis of Ir-BPy-NT-1/6 showed the presence of peaks due to C 1s, N 
1s, O 1s, Si 2p, S 2p, Ir 4f, which further confirmed the successful grafting of Ir-complex on the silica support (Figure S3). Si gave two peaks at $102.0 \mathrm{eV}$ (Si 2p) and $153.0 \mathrm{eV}$ (Si 2s), which confirms that the Si species are part of organosilica nanotube frameworks. ${ }^{32}$ The scan on N 1s region gave one peak at $400.4 \mathrm{eV}$ due to pyridinic nitrogen in the Ir complex. Ir $4 \mathrm{f}_{7 / 2}$ and $\operatorname{Ir} 4 \mathrm{f}_{5 / 2}$ peaks were observed at $62.6 \mathrm{eV}$ and $65.6 \mathrm{eV}$, respectively, suggesting the presence of $\operatorname{Ir}(\mathrm{III})$ species as it was in the precursor complex.
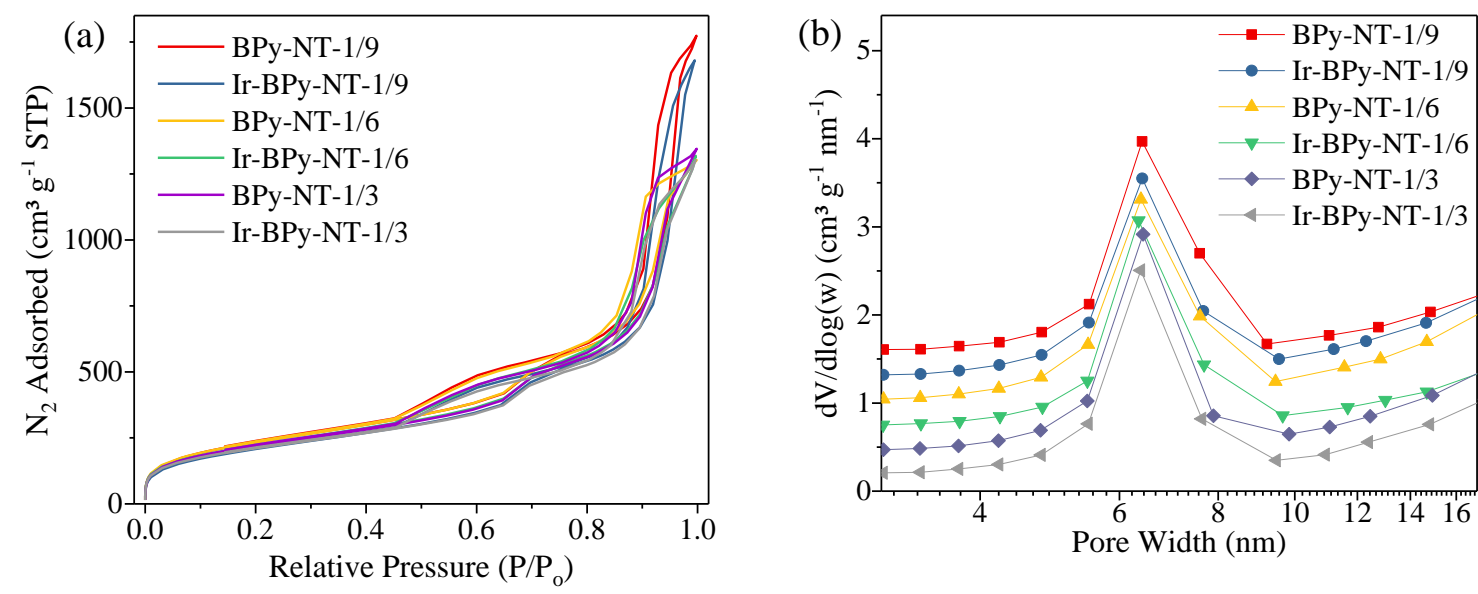

Figure 2. (a) Nitrogen adsorption-desorption isotherms and (b) pore size distribution curves calculated by the BJH method using the adsorption branch.

Table 1. Physicochemical properties of BPy-NT-x/y and Ir-BPy-NT-x/y samples

\begin{tabular}{llll}
\hline Sample & BET surface area $^{a}\left(\mathrm{~m}^{2} / \mathrm{g}\right)$ & Pore volume $^{b}\left(\mathrm{~cm}^{3} / \mathrm{g}\right)$ & Pore $\operatorname{size}^{c}(\mathrm{~nm})$ \\
\hline BPy-NT-1/9 & 861 & 2.64 & 6.4 \\
Ir-BPy-NT-1/9 & 810 & 2.50 & 6.4 \\
BPy-NT-1/6 & 856 & 2.01 & 6.4 \\
Ir-BPy-NT-1/6 & 766 & 1.94 & 6.3 \\
BPy-NT-1/3 & 805 & 1.95 & 6.4 \\
Ir-BPy-NT-1/3 & 768 & 1.93 & 6.4 \\
${ }^{a}$ The BET surface areas were calculated from the data in the relative pressure range of $\mathrm{P} / \mathrm{P}_{0}=$ \\
0.05 0.25; ${ }^{b}$ Pore volume were estimated from the amounts of $\mathrm{N}_{2}$ absorbed at a relative pressure of \\
P/P $\mathrm{P}_{0}=0.98 ;{ }^{c}$ Pore size distributions were calculated using the BJH method from adsorption branch. \\
\hline
\end{tabular}

The nitrogen adsorption-desorption isotherm of the samples corresponded to type IV, which is typical for mesoporous materials (Figure 2). All samples showed two hysteresis loops at the relative pressures $\mathrm{P} / \mathrm{P}_{0}=0.50-0.70$ and $\mathrm{P} / \mathrm{P}_{0}=0.85-0.99$, which are from the hollow nanotube channel and void space between the nanotubes, respectively. ${ }^{30}$ The textural properties of Ir-BPy-NT-x/y samples are almost the same as those of the BPy-NT-x/y samples. The physicochemical properties of BPy-NT-x/y and Ir- 
BPy-NT-x/y samples are listed in Table 1. The BET surface area and pore volume were slightly decreased following the incorporation of the iridium complex on the BPy-NT-x/y samples, while the pore diameter remained unchanged.

Catalytic performance of the catalysts was investigated for the hydrogenation of formic acid in a batch reactor. We systematically investigated the effect of different parameters (such as concentration of $\mathrm{CF}_{3} \mathrm{SO}_{3} \mathrm{H}, \mathrm{H}_{2}$ pressure, temperature and time) on $\mathrm{HCO}_{2} \mathrm{H}$ conversion and methanol selectivity in order to optimize the reaction system (Figure 3). As observed in earlier reports, an acid additive was necessary to improve the methanol selectivity and retard the decomposition of $\mathrm{HCO}_{2} \mathrm{H}$ into $\mathrm{CO}_{2}{ }^{22-23}$ In particular, $\mathrm{H}_{2} \mathrm{SO}_{4}$ and $\mathrm{CF}_{3} \mathrm{SO}_{3} \mathrm{H}$ were found to be the most effective and to result in higher methanol selectivity. Based on this finding, we tested both acids in our present system and found that the $\mathrm{CF}_{3} \mathrm{SO}_{3} \mathrm{H}$ was far more effective than $\mathrm{H}_{2} \mathrm{SO}_{4}$ (Table 2 vs. Table S2), and therefore all further reactions were performed in the presence of $\mathrm{CF}_{3} \mathrm{SO}_{3} \mathrm{H}$. Using $20 \mathrm{~mol} \%$ of $\mathrm{CF}_{3} \mathrm{SO}_{3} \mathrm{H}(\mathrm{pH} \sim 1)$, the Ir-BPy-NT-1/6 catalyst showed $19.6 \%$ methanol selectivity at a $\mathrm{HCO}_{2} \mathrm{H}$ conversion of $26 \%$. Further increase in $\mathrm{CF}_{3} \mathrm{SO}_{3} \mathrm{H}$ concentration did not improve the selectivity much, while at lower concentration of $\mathrm{CF}_{3} \mathrm{SO}_{3} \mathrm{H}(<20 \mathrm{~mol} \%)$, decomposition of $\mathrm{HCO}_{2} \mathrm{H}$ occurred at a faster rate (Figure 3a). Increase in $\mathrm{H}_{2}$ pressure resulted in lower $\mathrm{HCO}_{2} \mathrm{H}$ conversion and a steady increase in methanol selectivity (Figure $3 \mathrm{~b}$ ). This is probably due to the fact that higher $\mathrm{H}_{2}$ pressure suppresses the decomposition of $\mathrm{HCO}_{2} \mathrm{H}$ to form $\mathrm{CO}_{2}$. We did not observe any methanol formation via disproportionation of $\mathrm{HCO}_{2} \mathrm{H}$ when the reaction was performed in absence of $\mathrm{H}_{2}$. The result is in contrast to the reported homogeneous catalytic systems based on similar Ir complexes. ${ }^{20,23-24,29}$ In our heterogeneous system, free bipyridine ligands initiate the dehydrogenation of $\mathrm{HCO}_{2} \mathrm{H}$ at a faster rate in the absence of $\mathrm{H}_{2}$ and therefore $\mathrm{H}_{2}$ pressure was necessary for the production of methanol. Increase in temperature showed higher $\mathrm{HCO}_{2} \mathrm{H}$ conversion whereas the methanol selectivity started to decrease (Figure 3c). It was observed that at $60{ }^{\circ} \mathrm{C}$, both $\mathrm{HCO}_{2} \mathrm{H}$ conversion and methanol selectivity reached an optimum value and we therefore chose this temperature to perform further experiments. Ir-BPy-NT-1/6 catalyst showed a steady increase in $\mathrm{HCO}_{2} \mathrm{H}$ conversion between $8 \mathrm{~h}$ to $16 \mathrm{~h}$ followed by a typical decrease of the slope, while the methanol selectivity did not improve much even after $60 \mathrm{~h}$ of reaction (Figure $3 \mathrm{~d}$ ). 

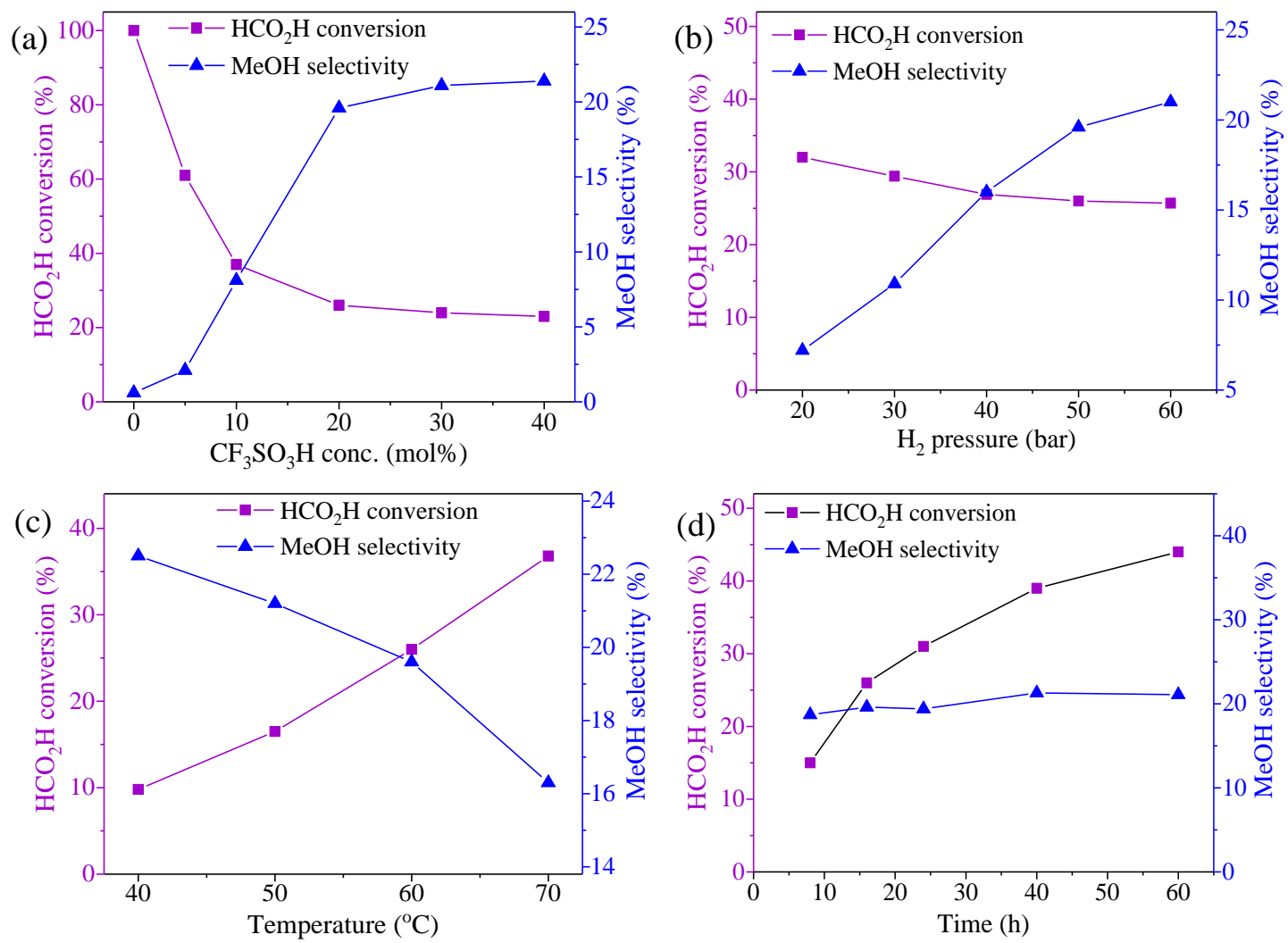

Figure 3. Plots of $\mathrm{HCO}_{2} \mathrm{H}$ conversion and $\mathrm{MeOH}$ selectivity versus (a) $\mathrm{CF}_{3} \mathrm{SO}_{3} \mathrm{H}$ concentration, (b) $\mathrm{H}_{2}$ pressure, (c) temperature and (d) time. Reaction conditions: (a) $1 \mathrm{~mL} 4 \mathrm{M} \mathrm{HCO}_{2} \mathrm{H}$, Ir-BPy-NT-1/6 = 20 $\mathrm{mg}, T=60{ }^{\circ} \mathrm{C}, \mathrm{H}_{2}=50 \mathrm{bar}, t=16 \mathrm{~h}$; (b) $1 \mathrm{~mL} 4 \mathrm{M} \mathrm{HCO}_{2} \mathrm{H}$, Ir-BPy-NT-1/6 = $20 \mathrm{mg}, T=60{ }^{\circ} \mathrm{C}$, $\mathrm{CF}_{3} \mathrm{SO}_{3} \mathrm{H}=20 \mathrm{~mol} \%, t=16 \mathrm{~h}$; (c) $1 \mathrm{~mL} 4 \mathrm{M} \mathrm{HCO}_{2} \mathrm{H}$, Ir-BPy-NT-1/6 = $20 \mathrm{mg}, \mathrm{CF}_{3} \mathrm{SO}_{3} \mathrm{H}=20 \mathrm{~mol} \%, \mathrm{H}_{2}$ $=50 \mathrm{bar}, t=16 \mathrm{~h}$; (d) $1 \mathrm{~mL} 4 \mathrm{M} \mathrm{HCO}_{2} \mathrm{H}$, Ir-BPy-NT-1/6 = $20 \mathrm{mg}, \mathrm{CF}_{3} \mathrm{SO}_{3} \mathrm{H}=20 \mathrm{~mol} \%, T=60{ }^{\circ} \mathrm{C}, \mathrm{H}_{2}=$ 50 bar.

Table 2. Results for the Ir-BPy-NT-x/y catalyzed hydrogenation of $\mathrm{HCO}_{2} \mathrm{H}$

\begin{tabular}{llllll}
\hline Entry & Catalyst $(20 \mathrm{mg})$ & $\begin{array}{l}\mathrm{CF}_{3} \mathrm{SO}_{3} \mathrm{H} \\
(\mathrm{mol} \%)^{a}\end{array}$ & $\begin{array}{l}\mathrm{HCO}_{2} \mathrm{H} \text { conv. } \\
\text { MeOH yield }\end{array}$ & $\begin{array}{l}\mathrm{MeOH} \\
\text { selectivity }\end{array}$ \\
\hline 1 & BPy-NT-1/9 & 20 & $<1$ & 0 & 0 \\
2 & Ir-BPy-NT-1/9 & 10 & 32 & 2.0 & 6.3 \\
3 & Ir-BPy-NT-1/9 & 20 & 24 & 4.6 & 19.2 \\
4 & Ir-BPy-NT-1/9 & 30 & 23 & 4.9 & 21.3 \\
5 & Ir-BPy-NT-1/6 & 10 & 37 & 3.0 & 8.1 \\
6 & Ir-BPy-NT-1/6 & 20 & 26 & 5.1 & 19.6 \\
7 & Ir-BPy-NT-1/3 & 20 & 37 & 4.6 & 12.4 \\
\hline \multicolumn{5}{l}{ Reaction conditions: $1 \mathrm{~mL} 4 \mathrm{M} \mathrm{HCO}_{2} \mathrm{H}, T=60{ }^{\circ} \mathrm{C}, \mathrm{H}_{2}=50$ bar, $t=16 \mathrm{~h} .{ }^{a} \mathrm{CF}_{3} \mathrm{SO}_{3} \mathrm{H}$}
\end{tabular}


To compare the effectiveness of our heterogeneous catalysts with their homogeneous counterpart, we prepared two additional homogeneous complexes $\left[\mathrm{Cp} * \operatorname{Ir}(\right.$ bpy $\left.)\left(\mathrm{H}_{2} \mathrm{O}\right)\right] \mathrm{SO}_{4}$ and $\left[\mathrm{Cp} * \operatorname{Ir}(\mathrm{bpy})\left(\mathrm{H}_{2} \mathrm{O}\right)\right] \mathrm{SO}_{4}$, and tested them under similar reaction conditions. The homogeneous catalysts were little better in terms of methanol selectivity and showed about six times higher TOF as compared to the heterogeneous catalysts (Figure 4). According to the earlier report on dehydrogenation of $\mathrm{HCO}_{2} \mathrm{H}$ over covalent triazine framework-based Ir catalysts, we assumed that the lower methanol selectivity for the Ir-BPy-NT catalysts could be due to the presence of free bipyridine groups in the vicinity of Ir that can increase the dehydrogenation rate of $\mathrm{HCO}_{2} \mathrm{H} .{ }^{33}$ To investigate the effect of free nitrogen on methanol selectivity in the homogeneously catalyzed reaction, all three kinds of nitrogen containing amines (i.e. primary, secondary and tertiary) were studied (Table S3). With respect to methanol selectivity (24.4\%) obtained over $\left[\mathrm{Cp} * \operatorname{Ir}(\right.$ bpy $\left.)\left(\mathrm{H}_{2} \mathrm{O}\right)\right] \mathrm{SO}_{4}$ catalyst, addition of the amines resulted in a large drop in selectivity. We can correlate these results with the behavior of our heterogeneous Ir-BPy-NT catalysts, where free bipyridine groups are always present to catalyze the dehydrogenation reaction. The results demonstrated a decrease in selectivity when the amount of free bipyridine is increased. For instance, Ir-BPy-NT-1/3 catalyst showed comparatively lower methanol selectivity as compared to Ir-BPy-NT-1/9 and Ir-BPy-NT-1/6 catalysts due to higher content of free bipyridine groups. Comparing the effectiveness between Ir-BPyNT-1/9 and Ir-BPy-NT-1/6 catalysts, Ir-BPy-NT-1/6 exhibited little better performance in terms of $\mathrm{HCO}_{2} \mathrm{H}$ conversion and methanol selectivity, although it contains little higher amount of free bipyridine. This could be due to the fact that Ir-BPy-NT-1/6 shows faster hydrogenation kinetics than dehydrogenation due to higher Ir content (Table S1).

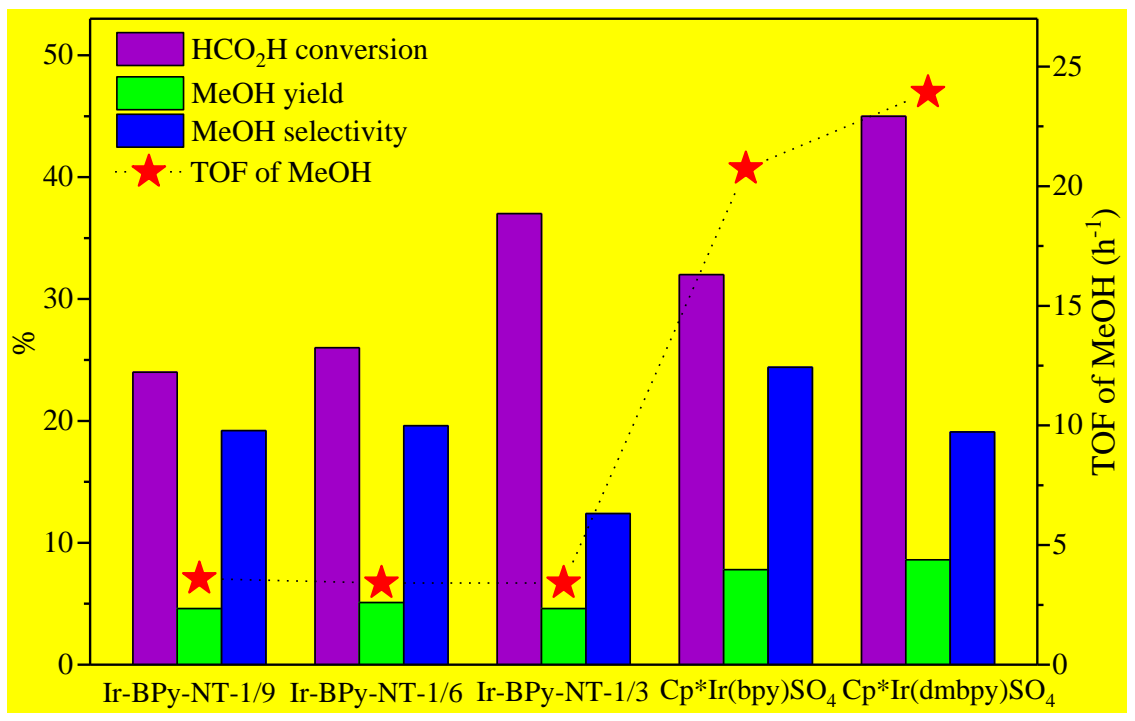


Figure 4. Comparison of catalytic activities between heterogeneous and homogeneous catalysts. Reaction conditions: $1 \mathrm{~mL} 4 \mathrm{M} \mathrm{HCO}_{2} \mathrm{H}, \mathrm{CF}_{3} \mathrm{SO}_{3} \mathrm{H}=20 \mathrm{~mol} \%$ w.r.t. $\mathrm{HCO}_{2} \mathrm{H}$, catalyst $=20 \mathrm{mg}$ (Ir-BPy-NT) and $1.5 \mathrm{mg}\left(\mathrm{Cp} * \operatorname{Ir}(\mathrm{bpy}) \mathrm{SO}_{4}\right.$ and $\left.\mathrm{Cp} * \operatorname{Ir}(\mathrm{dmbpy}) \mathrm{SO}_{4}\right) T=60{ }^{\circ} \mathrm{C}, \mathrm{H}_{2}=50$ bar, $t=16 \mathrm{~h}(\mathrm{Ir}-\mathrm{BPy}-\mathrm{NT})$ and $6 \mathrm{~h}$ $\left(\mathrm{Cp} * \operatorname{Ir}(\mathrm{bpy}) \mathrm{SO}_{4}\right.$ and $\left.\mathrm{Cp} * \operatorname{Ir}(\mathrm{dmbpy}) \mathrm{SO}_{4}\right)$.

The reusability of Ir-BPy-NT-1/6 catalyst was investigated after $16 \mathrm{~h}$ reaction times (still at in the kinetic regime, according to Figure 3). After each reaction cycle, the solid catalyst was removed from the reaction, washed with water for 3-4 times, dried at $50{ }^{\circ} \mathrm{C}$ and then reused for the next run. The solid catalyst retained its original catalytic activity up to four cycles (Figure 5a). A little decrease in $\mathrm{HCO}_{2} \mathrm{H}$ conversion was observed in each cycle which was due to the loss of catalyst during washing and drying. However, the selectivity and turnover number of methanol did not drop. After recycling, the obtained solid-free solution was colorless, indicating that the Ir complex was firmly coordinated with BPy-NT without leaching of Ir species. This was again confirmed by ICP analysis. Furthermore, the texture of the catalyst after $4^{\text {th }}$ cycle was investigated by TEM analysis (Figure $5 \mathrm{~b}$ ) and it was observed that the nanotube structure was maintained even after using it in highly acidic condition ( $\mathrm{pH} \sim 1$ ). XPS analysis also confirmed that the oxidation state of Ir did not change after reaction (Figure 5c), which was probably the main reason of unaffected performance of the catalyst.
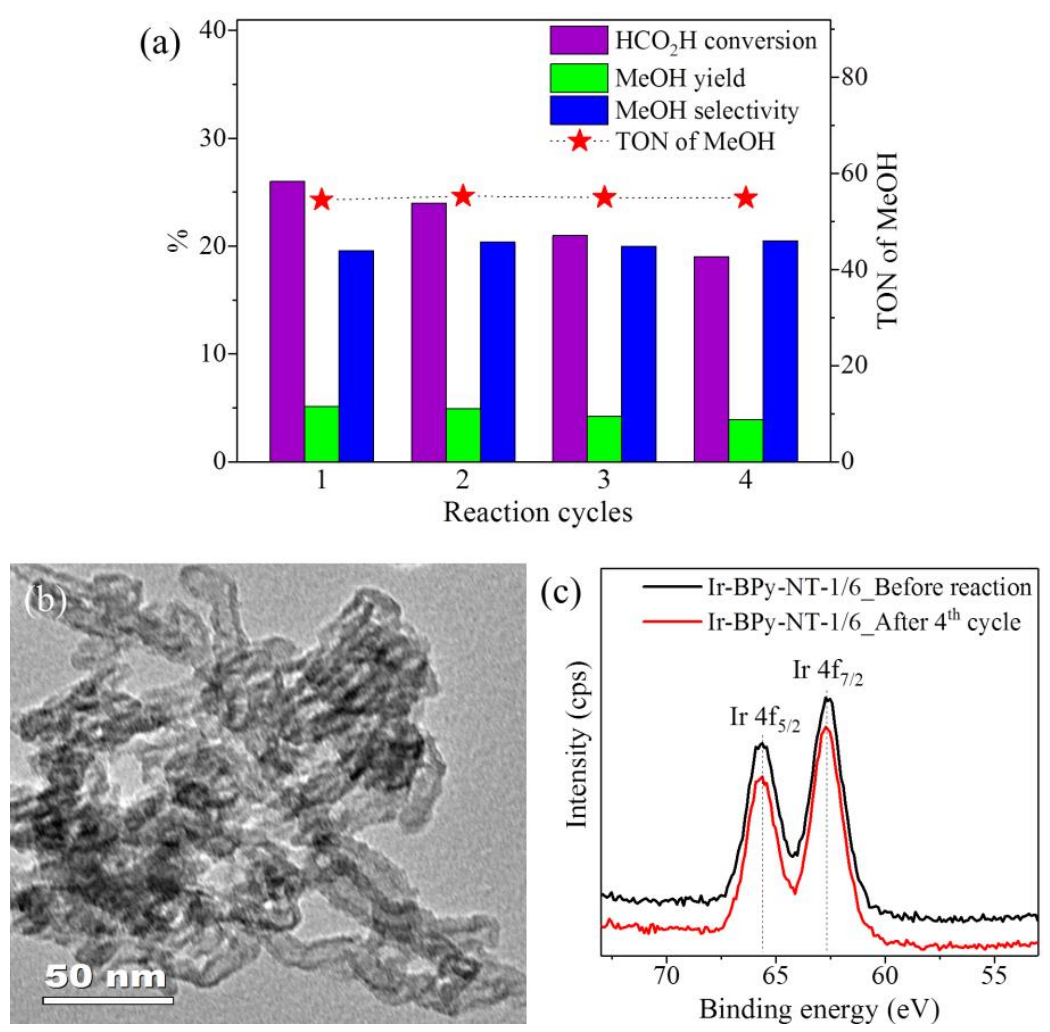
Figure 5. (a) Reusability studies of Ir-BPy-NT-1/6 catalyst. Reaction conditions: $1 \mathrm{~mL} 4 \mathrm{M} \mathrm{HCO}_{2} \mathrm{H}$, $\mathrm{CF}_{3} \mathrm{SO}_{3} \mathrm{H}=20 \mathrm{~mol} \%$ w.r.t. $\mathrm{HCO}_{2} \mathrm{H}$, catalyst $=20 \mathrm{mg}, T=60{ }^{\circ} \mathrm{C}, \mathrm{H}_{2}=50 \mathrm{bar}, t=16 \mathrm{~h}$. (b) $\mathrm{TEM}$ image of Ir-BPy-NT-1/6 catalyst after $4^{\text {th }}$ cycle. (c) XPS spectra of Ir (4f) in Ir-BPy-NT-1/6 catalyst before and after use.

\section{CONCLUSIONS}

In summary, we synthesized bipyridine-functionalized iridium-based solid catalysts and confirmed the successful grafting of the active molecular species on the organosilica support by different characterization techniques. The catalysts showed very interesting textural properties and high efficiency for the production of methanol form formic acid at low temperature. As compared to their homogeneous counterpart, the solid catalysts delivered comparable methanol selectivity and lower activity. On the other hand, the solid catalysts showed high recyclability in extremely low $\mathrm{pH}$, with all textural properties being well maintained after four consecutive cycles. The present study demonstrates the potential of organosilica nanotubes as substrates for the anchoring of different homogeneous catalysts. 


\section{REFERENCES}

1. Sordakis, K.; Tang, C.; Vogt, L. K.; Junge, H.; Dyson, P. J.; Beller, M.; Laurenczy, G., Homogeneous Catalysis for Sustainable Hydrogen Storage in Formic Acid and Alcohols. Chem. Rev. 2018, 118 (2), 372-433.

2. Yarulina, I.; Chowdhury, A. D.; Meirer, F.; Weckhuysen, B. M.; Gascon, J., Recent trends and fundamental insights in the methanol-to-hydrocarbons process. Nat. Catal. 2018, 1 (6), 398-411.

3. Wang, W.-H.; Feng, X.; Bao, M., Transformation of Carbon Dioxide to Formic Acid and Methanol. Sharma, S. K., Ed. Springer Singapore, 2018; Chapter 4, pp 53-87.

4. Olah, G. A.; Goeppert, A.; Prakash, G. K. S., Chemical Recycling of Carbon Dioxide to Methanol and Dimethyl Ether: From Greenhouse Gas to Renewable, Environmentally Carbon Neutral Fuels and Synthetic Hydrocarbons. J. Org. Chem. 2009, 74 (2), 487-498.

5. Bart, J. C. J.; Sneeden, R. P. A., Copper-zinc oxide-alumina methanol catalysts revisited. Catal. Today 1987, 2 (1), 1-124.

6. Dingerdissen, U.; Martin, A.; Herein, D.; Wernicke, H. J., The Development of Industrial Heterogeneous Catalysis. In Handbook of Heterogeneous Catalysis, Ertl, G.; Knözinger, H.; Schüth, F.; Weitkamp, J., Eds. Wiley-VCH: Weinheim: 2008.

7. Olah, G. A., Towards Oil Independence Through Renewable Methanol Chemistry. Angew. Chem., Int. Ed. 2013, 52 (1), 104-107.

8. Wang, W.-H.; Himeda, Y.; Muckerman, J. T.; Manbeck, G. F.; Fujita, E., $\mathrm{CO}_{2}$ Hydrogenation to Formate and Methanol as an Alternative to Photo- and Electrochemical $\mathrm{CO}_{2}$ Reduction. Chem. Rev. 2015, 115 (23), 12936-12973.

9. Li, Y.-N.; Ma, R.; He, L.-N.; Diao, Z.-F., Homogeneous hydrogenation of carbon dioxide to methanol. Catal. Sci. Technol. 2014, 4 (6), 1498-1512.

10. Goeppert, A.; Czaun, M.; Jones, J.-P.; Surya Prakash, G. K.; Olah, G. A., Recycling of carbon dioxide to methanol and derived products - closing the loop. Chem. Soc. Rev. 2014, 43 (23), 7995-8048.

11. Alberico, E.; Nielsen, M., Towards a methanol economy based on homogeneous catalysis: methanol to $\mathrm{H}_{2}$ and $\mathrm{CO}_{2}$ to methanol. Chem. Commun. 2015, 51 (31), 6714-6725.

12. Ashley, A. E.; Thompson, A. L.; O'Hare, D., Non-Metal-Mediated Homogeneous Hydrogenation of $\mathrm{CO}_{2}$ to $\mathrm{CH}_{3} \mathrm{OH}$. Angew. Chem., Int. Ed. 2009, 48 (52), 9839-9843.

13. Courtemanche, M.-A.; Légaré, M.-A.; Maron, L.; Fontaine, F.-G., Reducing $\mathrm{CO}_{2}$ to Methanol Using Frustrated Lewis Pairs: On the Mechanism of Phosphine-Borane-Mediated Hydroboration of $\mathrm{CO}_{2}$. J. Am. Chem. Soc. 2014, 136 (30), 10708-10717. 
14. Fontaine, F.-G.; Courtemanche, M.-A.; Légaré, M.-A., Transition-Metal-Free Catalytic Reduction of Carbon Dioxide. Chem. Eur. J. 2014, 20 (11), 2990-2996.

15. Riduan, S. N.; Zhang, Y.; Ying, J. Y., Conversion of Carbon Dioxide into Methanol with Silanes over N-Heterocyclic Carbene Catalysts. Angew. Chem., Int. Ed. 2009, 48 (18), 3322-3325.

16. Lu, Z.; Williams, T. J., Di(carbene)-Supported Nickel Systems for $\mathrm{CO}_{2}$ Reduction Under Ambient Conditions. ACS Catal. 2016, 6 (10), 6670-6673.

17. Balaraman, E.; Gunanathan, C.; Zhang, J.; Shimon, L. J. W.; Milstein, D., Efficient hydrogenation of organic carbonates, carbamates and formates indicates alternative routes to methanol based on $\mathrm{CO}_{2}$ and CO. Nat. Chem. 2011, 3, 609-614.

18. Balaraman, E.; Ben-David, Y.; Milstein, D., Unprecedented Catalytic Hydrogenation of Urea Derivatives to Amines and Methanol. Angew. Chem., Int. Ed. 2011, 50 (49), 11702-11705.

19. Han, Z.; Rong, L.; Wu, J.; Zhang, L.; Wang, Z.; Ding, K., Catalytic Hydrogenation of Cyclic Carbonates: A Practical Approach from $\mathrm{CO}_{2}$ and Epoxides to Methanol and Diols. Angew. Chem., Int. Ed. 2012, 51 (52), 13041-13045.

20. Miller, A. J. M.; Heinekey, D. M.; Mayer, J. M.; Goldberg, K. I., Catalytic Disproportionation of Formic Acid to Generate Methanol. Angew. Chem., Int. Ed. 2013, 52 (14), 3981-3984.

21. Savourey, S.; Lefèvre, G.; Berthet, J.-C.; Thuéry, P.; Genre, C.; Cantat, T., Efficient Disproportionation of Formic Acid to Methanol Using Molecular Ruthenium Catalysts. Angew. Chem., Int. Ed. 2014, 53 (39), 10466-10470.

22. Sordakis, K.; Tsurusaki, A.; Iguchi, M.; Kawanami, H.; Himeda, Y.; Laurenczy, G., Carbon Dioxide to Methanol: The Aqueous Catalytic Way at Room Temperature. Chem. Eur. J. 2016, 22 (44), 15605-15608.

23. Tsurusaki, A.; Murata, K.; Onishi, N.; Sordakis, K.; Laurenczy, G.; Himeda, Y., Investigation of Hydrogenation of Formic Acid to Methanol using $\mathrm{H}_{2}$ or Formic Acid as a Hydrogen Source. ACS Catal. 2017, 7 (2), 1123-1131.

24. Sordakis, K.; Tsurusaki, A.; Iguchi, M.; Kawanami, H.; Himeda, Y.; Laurenczy, G., Aqueous phase homogeneous formic acid disproportionation into methanol. Green Chem. 2017, 19 (10), 23712378.

25. Kar, S.; Kothandaraman, J.; Goeppert, A.; Prakash, G. K. S., Advances in catalytic homogeneous hydrogenation of carbon dioxide to methanol. J. $\mathrm{CO}_{2}$ Util. 2018, 23, 212-218.

26. Neary, M. C.; Parkin, G., Dehydrogenation, disproportionation and transfer hydrogenation reactions of formic acid catalyzed by molybdenum hydride compounds. Chem. Sci. 2015, 6 (3), 18591865. 
27. Yan, X.; Yang, X., Mechanistic Insights into Iridium Catalyzed Disproportionation of Formic Acid to $\mathrm{CO}_{2}$ and Methanol: A DFT Study. Organometallics 2018, 37 (10), 1519-1525.

28. Álvarez, A.; Bansode, A.; Urakawa, A.; Bavykina, A. V.; Wezendonk, T. A.; Makkee, M.; Gascon, J.; Kapteijn, F., Challenges in the Greener Production of Formates/Formic Acid, Methanol, and DME by Heterogeneously Catalyzed $\mathrm{CO}_{2}$ Hydrogenation Processes. Chem. Rev. 2017, 117 (14), 98049838.

29. Sasayama, A. F.; Moore, C. E.; Kubiak, C. P., Electronic effects on the catalytic disproportionation of formic acid to methanol by $\left[\mathrm{Cp}^{*} \mathrm{Ir}^{\mathrm{III}}(\mathrm{R}-\mathrm{bpy}) \mathrm{Cl}\right] \mathrm{Cl}$ complexes. Dalton Trans. 2016, 45 (6), 2436-2439.

30. Liu, X.; Li, X.; Guan, Z.; Liu, J.; Zhao, J.; Yang, Y.; Yang, Q., Organosilica nanotubes: largescale synthesis and encapsulation of metal nanoparticles. Chem. Commun. 2011, 47 (28), 8073-8075.

31. Liu, X.; Goto, Y.; Maegawa, Y.; Ohsuna, T.; Inagaki, S., Mesoporous organosilica nanotubes containing a chelating ligand in their walls. APL Mater. 2014, 2 (11), 113308.

32. Camarota, B.; Goto, Y.; Inagaki, S.; Onida, B., Basic Sites on Periodic Mesoporous Organosilicas Investigated by XPS and in Situ FTIR of Adsorbed Pyrrole. Langmuir 2011, 27 (3), 1181-1185.

33. Bavykina, A. V.; Goesten, M. G.; Kapteijn, F.; Makkee, M.; Gascon, J., Efficient production of hydrogen from formic acid using a Covalent Triazine Framework supported molecular catalyst. ChemSusChem 2015, 8 (5), 809-812. 


\section{Graphical Abstract}

Synopsis: Bipyridine-functionalized robust molecular heterogeneous catalysts were explored for the transformation of formic acid into methanol at low temperature.

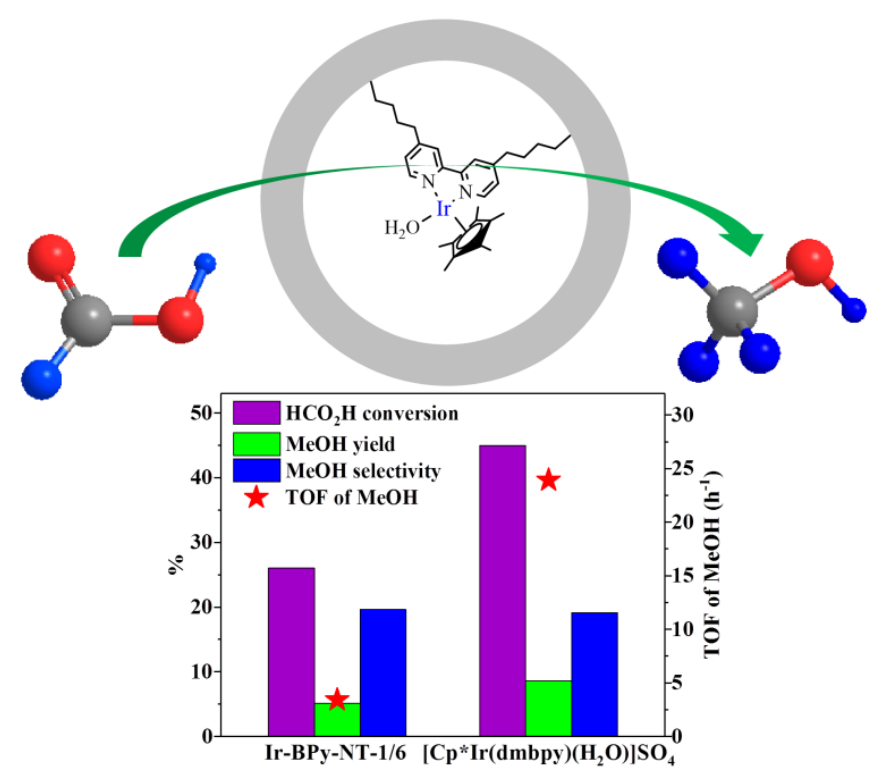

